\title{
Human Development in Kazakhstan: Problems and Methods of Analysis
}

\author{
Saule A.Kozhabaeva ${ }^{1 *}$, Baurzhan G. Mukan², Rakymzhan K. Yelshibayev ${ }^{3}$ \\ ${ }^{1}$ Kazakh University of Economics, Finance and International Trade, 7 Zhubanova Str, 010000, \\ Nur-Sultan, Kazakhstan \\ ${ }^{2}$ IEconomic Research Institute JSC, 65 Temirkazyk Str., 010000, Nur-Sultan, Kazakhstan \\ ${ }^{3}$ NARXOZ University, 55 Zhandosova Str., 050035, Almaty, Kazakhstan
}

\begin{abstract}
Human potential assessment involves determining a person's ability to live a healthy, long, and dignified life. The purpose of this article is to analyze the dynamics of the main indicators for measuring the human development index in Kazakhstan. The information base for scientific research was official statistical information, articles in domestic and foreign scientific publications. Within the framework of the study, general scientific, including analytical, statistical, graphical methods were used with the help of comparative, logical analysis tools. Within the framework of the analytical method, an analysis of indicators of the quality of life was carried out, including several blocks. The application of the analytical method made it possible to determine the trends of human development, assess the health, education level, and income level of people. Within the framework of the statistical method, the analysis and concretization of individual indicative indicators were carried out. During the study, a block of indicators for assessing the human development index (hereinafter referred to as the HDI) was identified, and their analysis and differentiation of levels by regions and types of localities was carried out. The analysis of the real gross product per capita and the indicator of real money income in Kazakhstan was carried out. As a result of the analysis of the quintile division of the population into groups, one of the main reasons for the increase in the existing inequality in income distribution was identified as the imperfection of the existing system of income redistribution in the economy.

Keywords: human development, human potential, human development index, life expectancy, GDP per capita, the concept of human development.
\end{abstract}

For citation: Kozhabaeva, S.A., Mukan, B.G. \& Yelshibayev R.K. (2021). Human Development in Kazakhstan: Problems and Methods of Analysis. Economics: the Strategy and Practice, 16(4), 174-187, https://doi. org/10.51176/1997-9967-2021-4 -174-187

* Corresponding author: Kozhabaeva S.A. - Candidate of Economic Sciences, Associate Professor of the Department of Economics; Kazakh University of Economics, Finance and International Trade; Republic of Kazakhstan, 010000, Nur-Sultan, Zhubanova st., 7; 87751426856, e-mail: s_kozhabayeva@kuef.kz.

Conflict of interests: the authors declare that there is no conflict of interest.

Financial support: The study was not sponsored (own resources).

The article received: 06.12 .2021

The article approved for publication: 24.12 .2021

Date of publication: 30.12 .2021 


\title{
Қазақстандағы адам дамуы: мәселелері мен талдау әдістері
}

\author{
Қожабаева С.А. ${ }^{1 *}$, Мұқан В.Г. ${ }^{2}$, Елшібаев Р.Қ. ${ }^{3}$ \\ 1 Экономика вылымдарының кандидаты, Қазақ экономика, құаржы және халықаралық сауда \\ университеті, Қазақустан Республикасы, Жұбанова к., 7, 010000, Нұр-Сұлтан, Қазақсстан \\ ${ }^{2}$ «кономикалық зерттеулер институты» АҚ. Темірқазық к., 65, 010000, Нұр-Сұлтан, Қазақстан \\ ${ }^{3}$ НАРХОЗ университеті, Жандосов к., 55, 050035, Алматы, Қазақсстан
}

\begin{abstract}
Түйін
Адам мүмкіндіктерінің ең маңыздысы - лайықты өмір сүру деңгейіне қол жеткізу және салауатты және ұзақ өмір сүру мүмкіндігі. Бұл мақаланың мақсаты - Қазақстандағы адам дамуы индексін өлшеудің негізгі көрсеткіштерінің динамикасын талдау. Ғылыми зерттеулердің ақпараттық базасы адам дамуының негізгі көрсеткіштері саласындағы ресми статистикалық ақпарат, сонымен қатар жақын және алыс шетелдердің бірқатар отандық ғылыми және мерзімді басылымдары мен журналдары болды. Ғылыми зерттеулерді жүргізу барысында жалпы ғылыми зерттеу әдістемесі, оның ішінде аналитикалық әдіс, статистикалық әдіс, сонымен қатар салыстырмалы, логикалық және статистикалық талдау құралдарын пайдалана отырып, ақпаратты графикалық түсіндіру әдісі қолданылды. Аналитикалық әдіс аясында бірқатар блоктарды қамтитын өмір сапасының көрсеткіштерінің кешеніне талдау жасалды. Аналитикалық әдіс адамдардың денсаулығын, білім деңгейін және нақты табыс деңгейін бағалауға мүмкіндік беретін көрсеткіштерді талдау арқылы адам дамуы саласындағы экономикалық жетістіктердің ағымдағы жағдайын анықтауға мүмкіндік берді. Статистикалық әдіс аясында жеке индикативті көрсеткіштерді талдау және нақтылау жүргізілді. Зерттеу барысында адами даму индексін (бұдан әрі - АДИ) бағалау үшін көрсеткіштер блогы айқындалды, оларға талдау жүргізілді және өңірлер мен елді мекендердің типтері бойынша деңгейлер сараланды. Қазақстандағы жан басына шаққандағы нақты жалпы өнімнің талдауы және табыстардағы барлық диспропорцияларды ескере отырып, нақты ақшалай табыстар көрсеткіші жасалды. Халықтың топтарға квинтилдік бөлінуін талдау нәтижесінде табыстарды бөлудегі қалыптасқан теңсіздіктің ұлғаюының негізгі себептерінің бірі - бұл табыстарды қайта бөлудің қолданыстағы жүйесінің жетілмегендігі анықталды. Қазақстан Республикасының экономикалық саясатының басым міндеттерінің бірі адами даму болып табылады. Осыған байланысты кедейлікті азайту және өмір сүру сапасын арттыру бойынша адамға бағытталған саясатты әзірлеу және іске асыру қажеттілігі негізделген.
\end{abstract}

Түйін сөздер: адам дамуы, адам әлеуеті, адам дамуының индексі, өмір сүру ұзақтығы, жан басына шаққандағы ЖІӨ, адам дамуы концепциясы.

Дәйексөз алу үшін: Қожабаева С.А., Мұқан В.Г., Елшібаев Р.Қ. (2021). Қазақстандағы адам дамуы: мәселелері мен талдау әдістері. Экономика: стратегия және практика, 16(4), 174-187, https://doi.org/10.51176/1997-9967$\underline{2021-4-174-187}$

* Хат-хабаршы авторы: Қожабаева С.А. - экономика ғылымдарының кандидаты, экономика кафедрасының доценті; Қазақ экономика, қаржы және халықаралық сауда университеті; Жұбанова к., 7, 010000, Нұр-Сұлтан, Қазақстан, 87751426856, e-mail: s_kozhabayeva@kuef.kz.

Мүдделер қақтығысы: авторлар мүдделер қақтығысының жоқтығын мәлімдейді.

Қаржыландыру. Зерттеу демеушілік қолдау көрсеткен жоқ (меншікті ресурстар).

Мақала редакцияға түсті: 06.12 .2021

Жариялау туралы шешім қабылданды: 24.12.2021

Жарияланды: 30.12 .2021 


\title{
Развитие человеческого потенциала в Казахстане: проблемы и методы анализа
}

\author{
Кожабаева С.А. ${ }^{1 *}$, Мукан Б.Г. ${ }^{2}$ Елшибаев Р.К. ${ }^{3}$ \\ ${ }^{1}$ Казахский университет экономики, финансов и международной торговли, ул.Жубанова,7, \\ 010000, Нур-Султан, Казахстан \\ ${ }^{2}$ ААО «Институт экономических исследований», ул. Темірқазық 65, 010000, Нур-Султан, \\ Казахстан \\ ${ }^{3}$ Университет НАРХОЗ, ул. Жандосова, 55, 050035, г. Алматы, Казахстан
}

\begin{abstract}
Аннотация
Оценка человеческого потенциала предполагает определение возможностей человека проживать здоровую, долгую и достойную жизнь. Цель данной статьи - анализ динамики основных индикаторов измерения индекса человеческого развития в Казахстане. Информационной базой для научного исследования явились официальная статистическая информация, статьи в отечественных и зарубежных научных изданиях. В рамках исследования были использованы общенаучный, в том числе аналитический, статистический, графический методы при помощи сравнительных, логических инструментов анализа. В рамках аналитического метода был проведен анализ индикаторов качества жизни, включающих ряд блоков. Применение аналитического метода позволило определить тенденции человеческого развития, оценить здоровье, уровень образования и уровень доходов людей. В рамках статистического метода были проведены анализ и конкретизация отдельных индикативных показателей. В ходе исследования выделены блок показателей для оценки индекса человеческого развития (далее - ИЧР) и проведен их анализ и дифференциация уровней по регионам и типам местности. Проведен анализ реального валового продукта на душу населения и показателя реальных денежных доходов в Казахстане. В результате анализа квинтильного деления населения на группы выявлена одна из основных причин усиления существующего неравенства в распределении доходов, как несовершенство существующей системы перераспределения доходов в экономике. Одной из приоритетных задач экономической политики Республики Казахстан является человеческое развитие. В этой связи, обоснована необходимость разработки и реализации человекоориентированной политики по снижению бедности и повышению качества жизни.
\end{abstract}

Ключевые слова: человеческое развитие, человеческий потенциал, индекс человеческого развития, ожидаемая продолжительность жизни, ВВП на душу населения, концепция человеческого развития.

Для цитирования: Кожабаева С.А., Мукан Б.Г., Елшибаев Р.К. (2021). Развитие человеческого потенциала в Казахстане: проблемы и методы анализа. Экономика: стратегия и практика, 16(4), 174-187, https://doi. org/10.51176/1997-9967-2021-4-174-187

* Корреспондирующий автор: Кожабаева Сауле Аманкельдиевна - кандидат экономических наук, доцент кафедры «Экономика»; Казахский университет экономики, финансов и международной торговли; ул.Жубанова, 7, 010000, Нур-Султан, Казахстан, 87751426856, e-mail: s_kozhabayeva@kuef.kz.

Конфликт интересов. авторы заявляют об отсутствии конфликта интересов.

Финансирование. Исследование не имело спонсорской поддержки (собственные ресурсы).

Статья поступила в редакцию: 06.12.2021

Принято решение о публикации: 24.12 .2021

Опубликовано: 30.12 .2021 


\section{Введение}

Современное понимание человеческого развития было сформировано под влиянием теоретических разработок А.Сена. В своей работе «Развитие как расширение возможностей» им рассматривается процесс человеческого развития как расширение возможностей людей проживать здоровую и продолжительную жизнь, получать знания, a не только повышать материальное и экономическое благосостояние. Так, одно из современных мыслей по вопросу человеческого развития было описано Currie, J., \& Schwandt, Н. в работе «Mortality inequality: The good news from a county-level approach», где рассматривается, что расширение возможностей человека должно происходить через расширение прав, человеческой свободы и выбора. [1, с. 37]

Известный на сегодняшний день науке и практике метод измерения национальной доходности и богатства вызывает всё более критический отзыв в научных кругах, повышая интерес к показателям человеческого развития. [2, с. 75] Понятие «человеческое развитие» считается абстрактным, однако оно измеримо, если использовать такие показатели, которые количественно характеризуют основные вопросы человеческого развития. Основной стратегический инструмент концепции человеческого развития - ИЧР. В основе ИЧР лежит комплекс числовых показателей уровня жизни людей в стране, позволяющих характеризовать качественные и количественные характеристики социальной и экономической дифференциации развития социума. Целью данной статьи является анализ динамики основных индикаторов измерения индекса человеческого развития в Казахстане.

Экспертами $\mathrm{OOH}$ была опубликована Концепция человеческого потенциала (развития) (далее - Концепция), согласно которой основной целью развития экономики является не рост агрегированного показателя ВВП (валовой внутренний продукт), а рост возможностей человека, а именно расширение прав и свобода выбора. [3, с. 470] Концепция приобрела глобальность и отражается во многих документах программного формата организаций международного уровня, которые работают под эгидой ПРООН (ООН).

Сущность Концепции состоит в том, что сама по себе жизнь человека имеет ценность не потому, что человек обладает способностью производить товары и услуги, а именно потому, что представляет собой основную цель развития человека. $[4$, с. 10$]$
В 1995 году был разработан первый Национальный Отчёт, в котором была прописана Концепция, которая сегодня представляется альтернативным путём выделения приоритетов в развитии всей экономической системы.

В Республике Казахстан после разработки документа «Национальный отчёт о человеческом развитии» человеческое развитие приобрело важную роль в планировании и определении основополагающих приоритетов и определяется как альтернативный путь. Во всех официальных плановых документах страны отражаются те социальные потребности населения, которые обозначены в документе-Стратегии «Казахстан - 2030». Долгосрочное развитие страны также реализуется на идеологической платформе-Стратегии «Казахстан - 2050», в которой обозначена идея «единой нации сильных и ответственных людей». Тот принцип человекоцентричности, который всё чаще в последнее время является идеей национальных программ, прописан также в Национальном плане развития РК до 2025 года, который имеет конечной целью улучшение и усиление качества жизни населения, а также увеличение благосостояния людей. Кроме того, ежегодные послания Президента Казахстана содержат принципы и концепции человеческого развития.

Такая ориентированность на человекоразвитие может выступать показателем изменений в общем развитии страны. Одним из основных показателей ситуационных изменений в стране является огромное внимание к человекоориентированной политике, где вопросы социальных нужд, в том числе снижение бедности постепенно выходят на первые позиции в планах страны.

\section{Литературный обзор}

Как показывает литературный обзор, современные исследования по данной тематике, можно назвать как активно развивающимися. Однако основные теоретические аспекты человеческого развития исследовались и в гораздо ранний временной период. Так, ещё Аристотелем были заложены общие принципы социальных исследований человеческого потенциала, через представление двух составляющих: физических возможностей человека (здоровье, долголетие и физическая сила людей) и духовных возможностей (добродетельство, потребности в духовном богатстве).

В. Зомбартом развивается данный взгляд и обосновывается расширение комплексных 
характеристик понятия «человеческий потенциал» через призму системы оценок уже укорененных и устоявшихся обычаев и нравов людей. В.Зомбарт отмечает, что такая форма человеческого развития имеет склонность к историческим изменениям в ходе экономических и социальных трансформаций. [5, с. 260]

Теория развития человеческого ресурса активно исследовалась неоклассическим направлением экономической науки. В своих трудах Г.Беккер выделяет образование как одну из форм проявления человеческого ресурса и источник будущих заработков и «удовлетворений». По мнению неоклассиков, человеческий ресурс создается через инвестиции в развитие личности, затрат на образование, на подготовку рабочей силы, на миграцию. [6, с. 115]

На современное понимание человеческого развития оказали влияние теоретические разработки А.Сен, который в своей работе «Развитие как расширение возможностей» рассматривает процесс человеческого развития как расширение возможностей людей проживать здоровую и продолжительную жизнь, получать знания, а не только повышать материальное и экономическое благосостояние. Так, одно из современных мыслей по вопросу человеческого развития было описано Currie J., \& Schwandt H. в работе «Mortality inequality: The good news from a county-level approach», где рассматривается расширение возможностей человека через предоставление прав, человеческой свободы и выбора. [1, с. 37]

Взаимосвязь между экономическими и социальными проявлениями конкретизирует Г.Зиммель. Общетеоретический анализ дополняется Г.Зиммелем социально-экономическим измерением, в результате которого сделан вывод о том, что в рыночной системе человеческое развитие проявляется в комплексе как в экономическом, так и в социальном контекстах. В экономическом контексте источником всякого человеческого развития являются деньги. В социальном контексте человеческое развитие тождественно с процессом развития сущности человека, с повышением его социальных потребностей.

Таким образом, Г.Зиммель выделяет основные формы проявления человеческого развития: состояние здоровья, долголетие и духовность, богатство развития сознания, способности к интеллектуальной деятельности. [7, с. 20] Влияние физического состояния человека на его общее развитие также отражаются и в современных подходах к исследованию индекса человеческого развития. В своих работах Faden R. and Leplege A. выявляют проблемные точки в предоставлении медицинских услуг, в том числе неисследованные вопросы о степени удовлетворённости пациентов, как одного из тормозящих факторов развития медицинских услуг в его стране. [8, с. 168]

В работе «Влияние социальноэкономических факторов на готовность населения поддерживать и накапливать капитал здоровья» коллектив авторов Спанкулова Л.С., Нурулы Е., Керимбаева А.Р. и Аймаханова А.Ш. акцентирует внимание на системе медицинского страхования, благодаря которому государство сохранит гарантированный объём бесплатной медицинской помощи, что окажет влияние в среднесрочном периоде на ряд индикаторов человеческого развития, в том числе на продолжительность жизни населения. [9, c. 188]

\section{В рамках $\stackrel{\text { Методы }}{\text { исследования были }}$} использованы общенаучный, в том числе аналитический, статистический, графический методы при помощи сравнительных, логических инструментов анализа. В рамках аналитического метода был проведен анализ индикаторов качества жизни, включающих ряд блоков. Применение аналитического метода позволило определить тенденции человеческого развития, оценить здоровье, уровень образования и уровень доходов людей. В рамках статистического метода были проведены анализ и конкретизация отдельных индикативных показателей. Информационной базой для научного исследования явились официальная статистическая информация, статьи в отечественных и зарубежных научных изданиях. Разработке комплексной методики, с высокой точностью, отображающей уровень жизни населения, наиболее важных черт развития человека в обществе, уделялось внимание и ранее. В экономической литературе существует множество разных подходов к оценке компонентов индекса человеческого развития, тем не менее, отсутствует методика по его комплексной оценке.

Существующие подходы и методы оценки человеческого развития позволяют выделить основные критерии их классификации по экономическому уровню:

- микроуровень (оценка человеческого развития отдельного индивидуума, сумма которых даёт получение общей оценки человеческого развития организации в целом); 
- мезоуровень (человеческое развитие крупных корпорации);

- макроуровень (человеческое развитие в рамках национальных экономик);

- мегауровень (оценка человеческого развития в мировом, глобальном масштабе).

В рамках нашего исследования интересующий нас метод оценки человеческого развития на макроуровне (а также мега- и мезо- уровнях) - расчёт индекса человеческого развития. Это агрегированный показатель, при расчёте которого учитываются такие факторы, как: факторы здоровья (ожидаемая продолжительность жизни), уровень образования людей, факторы благосостояния людей (ВВП на душу населения).

В 1990 г, в Докладе ПРООН о развитии человека были введены в оборот понятия «человеческое развитие» и «индекс развития человеческого потенциала». Отличительная особенность данной концепции от предшествующих заключается в усилении фокуca на человеке, на провозглашении благосостояния человека единственной и основной целью развития общества и экономических систем. Индекс развития человеческого потенциала позволяет измерить долголетие (продолжительность жизни), объёмы знаний (также доступ к базовым источникам). Эмпирический приём сопоставления данных, который проводится на основе известного статистического метода объединения разномерных показателей, позволяет сделать расчёт Индекса развития человеческого потенциала с учётом в нем социальной составляющей. Сущность метода заключается в том, что рассчитывается средняя арифметическая величина (состоит из величин: реальный ВВП на душу населения, ожидаемая продолжительность жизни при рождении, уровень образования, бедности, безработицы населения), составляются индикаторы уровня жизни и агрегируются в индекс развития человеческого потенциала $[10$, с. 196]:

$$
\mathrm{J}_{\text {чк }}=1 / 5 \mathrm{SJ}_{\mathrm{x}}
$$

где:

Јчк - социализация человеческого капитала;

Jx1 -ожидаемая продолжительность жизни при рождении;

$\boldsymbol{J} x 2$ - уровень образования населения (сумма индекса грамотности взрослого человека и индекса совокупной доли учащихся);

$\boldsymbol{J} 33$ - уровень бедности населения (население стратифицируется по уровню доходов);
$\boldsymbol{J} x 4$ - уровень безработицы населения;

$\boldsymbol{J} x 5$ - реальное ВВП на душу населения.

По данной методике каждая составляющая сводного индекса рассчитывается как фиксированный стандарт максимального и минимального значений: $\mathrm{Y}=$ (фактическое значение $\boldsymbol{y}_{i}-$ минимальное значение $\boldsymbol{y}_{i}$ ) / (максимальное значение $\boldsymbol{y}_{i}-$ минимальное значение $\boldsymbol{y}_{\text {).). }}$.

При расчёте индекса продолжительности жизни за максимальный уровень принимается 85 лет, за минимальный уровень - 25 лет. Стандарты индекса уровня образования составляются соответственно $0 \%$ и 100\%. Формула определения индекса бедности: 1 - доля населения, доходы которых ниже прожиточного минимума. Индекс безработицы определяется как: 1 - доля безработных к количеству экономически активного населения.

Комплексная оценка уровня жизни людей возможна при исследовании каждого из вышеперечисленных блоков показателей, отражающих уровень жизни в сравниваемых странах или регионах.

\section{Результаты/обсуждение}

Важнейшим индикатором социальноэкономического развития стран является система национальных счетов (далее по тексту СНС). Методология ПРООН предлагает в качестве показателей такие, как валовой внутренний продукт на душу населения, в разрезе регионов валовой региональный продукт, который рассчитывается через производственный метод. [10, с. 198] Однако данный метод измерения национальной доходности и богатства вызывает всё более критический отзыв у современных экономистов, вызывая повышенный интерес к альтернативным методам вычисления национального богатства.

До сих пор считалось, что уровень государственного дохода и есть один из самых верных показателей развития человека. Да, экономический рост представляет собой средство для улучшения благополучия людей. Но совершенно ошибочно предполагать, что экономический рост воплощается в увеличении уровня развития человека.

Если проводить анализ человеческого развития через оценку динамики удельного веса валового регионального продукта, то можно получить искаженную мнимую экономическую ситуацию - зачастую получается высокий уровень благополучия населения в регионе, не соответствующий 
реальной действительности (особенно в странах сырьевой направленности). Ну невозможно через $\mathrm{CHC}$, через экономический рост, когда речь идёт об объёмах произведённых товаров и услуг, отразить ни уровень здоровья нации, ни уровень продолжительности жизни, ни степень решения экологических проблем, ни степень доступности народонаселения к ресурсам. Тогда как именно эти показатели позволяют отразить и измерить реальный уровень человеческого развития.

Само по себе понятие «человеческое развитие» является абстрактным. Но его можно измерить, использовав такие показатели, которые позволяют количественно характеризовать основные вопросы человеческого развития. На самом деле для улучшения благосостояния и развития человека намного значимым является не сам факт экономического роста, а то, как и каким образом получают реализацию результаты этого роста, например, используют ли их для улучшения вооружения или для увеличения объемов производимых продуктов питания. Именно поэтому многие страны мира разрабатывают комплексы индикаторов и показателей результатов человеческого развития, позволяющих оценить именно реализацию результатов экономического роста. В эти комплексы включены такие показатели, как: ожидаемая продолжительность жизни людей, смертность людей (в том числе детей до 5 лет), уровень грамотности населения, возможность доступа к питьевой воде, равенство возможностей женщин и мужчин в политике, в обучении и других сферах жизнедеятельности человека и т.д. [11, с. 205]

Одним из агрегированных показателей уровня развития людей в стране является ИЧР, отражающий такие важные аспекты общественной жизни как уровень и качество жизни. Через ИЧР можно измерить степень влияния достижений экономики на здоровье людей, уровень образования и фактический уровень их доходов. Индекс не оценивает человеческий прогресс в развитии в краткосрочный период и компоненты индикатора не могут сразу среагировать на изменения в политике, но в качестве измерителя прогресса в среднесрочной или долгосрочной перспективах он вполне подходит. ИЧР в агрегированном виде может скрыть факт того, что группы народонаселения страны имеют дифференцированные уровни своего развития (обусловленные регионом, типом местности), поэтому получить более детальную и полную информацию можно через его разукрупнение. С этой целью ИЧР делят на три блока.
В первый блок оценки качества жизни людей включаются здоровье населения, демография (уровень рождаемости, уровень смертности), продолжительность жизни. Таким образом, первым блоком характеризуется реальное состояние населения с позиции его благополучия. Как мы отмечали чуть выше, высокий уровень доходности населения и экономический рост в целом никак не смогут подменить ситуацию низкой рождаемости, высокой детской смертности, низкой продолжительности жизни и высокий уровень заболеваемости населения. Именно через измерение и оценку последних показатели можно получить полную картину качества жизни населения страны без дополнительных исследований.

Факторы второго блока показывают степень удовлетворённости людей условиями жизни, то есть достатком, жильём, питанием, работой, также удовлетворённостью социальным положением в государстве, то есть организацией власти, способностью решения острых проблем социального характера, доступностью медицинских и образовательных услуг, экологической ситуацией в стране. Для того, чтобы реалистично оценить эту группу факторов, целесообразно использование социологических опросов граждан страны. Из всех прямых статистических показателей в мире самым реалистичным является уровень самоубийств. Почему именно этот показатель? Потому что он отражает степень крайности, социальный протест и в комплексном анализе считается самым показательным.

Факторы третьего блока связаны с двумя предыдущими, но принципиально включает группу показателей духовного развития. Единицами измерения выступают официальная уголовная и социальная статистика по убийству, грабежам и тяжким телесным повреждениям, брошенным пожилым родителям и детям, алкогольным психозам. Увеличение этих показателей означает ухудшение нравственного состояния общества страны. Такая ситуация, в первую очередь, объясняется кризисом семьи как института социального характера. Семья, которая призвана обеспечивать социализацию человека, в том числе подростков, сегодня занимает роль вспомогательную, предлагая сохранение традиционных разделения гендерных позиций. [12, с. 295-296]

Таким образом, через разукрупнение ИЧР, основываясь на результатах анализа показателей, входящих в состав блоков таких, как уровень продолжительности жизни, 
уровень образования, уровень развития медицины и здравоохранения, показатель валового национального продукта на душу населения, уровень духовного развития и социальной удовлетворённости можно сделать реалистичную оценку качества жизни людей. [13, с. 167]

На наш взгляд очень важно понимание того, что несмотря на то, что индекс человеческого развития является стартовой точкой, вся концепция человеческого развития гораздо сложнее и обширнее и охватить её одним (пусть агрегированным или даже разукрупнённым) показателем невозможно.
То есть, тем не менее, индекс человеческого развития тоже не является исчерпывающим показателем, поскольку он не может отразить все важные стороны развития.

Фактор первого блока оценки ИЧР - индекс продолжительности жизни - определяется показателем ожидаемой продолжительности жизни населения. Если попытаться сделать анализ этого показателя в Казахстане, то здесь за весь анализируемый период (рисунок 1) продолжительность жизни была увеличена почти на 4 года. Казахстаном достигнут позитивный результат по этому показателю, но в сравнении с Европой, он отстаёт от средних значений.

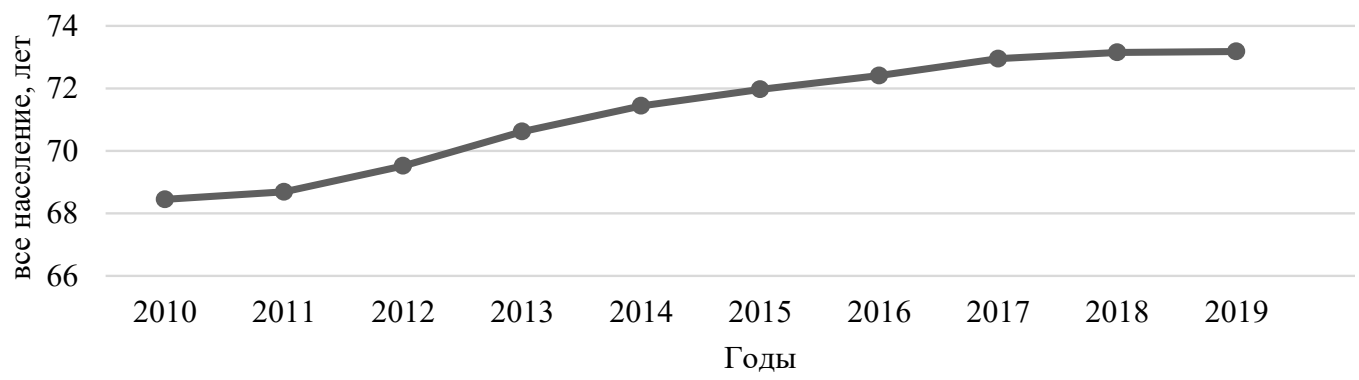

Рисунок 1 - Продолжительность жизни населения за 2010 - 2019 гг, лет

Figure 1 - Life expectancy of the population at birth for 2010 - 2019, years

Примечание - Составлено авторами по источнику [14]

На конец 2018 года Казахстан занимал 50-ю позицию из 189 стран. А это означает, что стране есть куда стремиться. В целом, за весь период с 2010 по 2019 годы, из рисунка 1 можно наблюдать прогрессивную динамику по продолжительности жизни. Международной методикой измерения ожидаемой продолжительности жизни за минимальные значения принимаются значения в 25 лет, а за максимальные - 85 лет. Но, тем не менее, самым устойчивым - условий и качества жизни населения является её средняя величина, то есть средняя продолжительность жизни. В Казахстане средние значения продолжительности жизни, особенно в последние годы, имеют тенденцию к увеличению.

Индекс продолжительности жизни также может быть определён через показатель предполагаемой продолжительности жизни младенцев, детей, родившихся в анализируемый период.

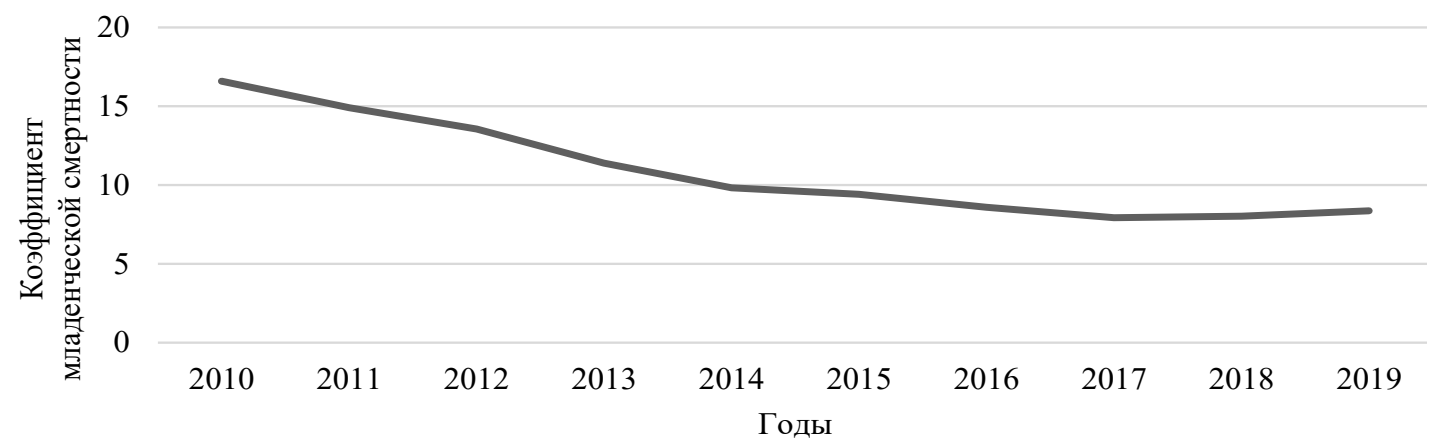

Рисунок 2 - Коэффициент младенческой смертности, на 1000 родившихся

Figure 2 - Infant mortality rate, per 1000 births

Примечание - Составлено авторами по источнику [14]

Экономика: стратегия и практика. Т. 16, № 4, 2021 / Economics: the Strategy and Practice. Vol. 16. No 4, 2021 


\section{DEMOGRAPHY, HUMAN RESOURCES AND THE LABOR MARKET}

Из рисунка 2 можно наблюдать уменьшение с 2010 года показателя младенческой смертности вплоть до 2017 года. Начиная с 2017 года этот показатель увеличивается, что находит отражение на общем показателе индекса человеческого развития в Казахстане. На динамику этого показателя оказывают влияние факторы второго и третьего блоков, такие как уровень жизни, половая, этническая и расовая принадлежность. Так, например, население с высоким уровнем дохода, имеющие полноценное питание и получаю- щие квалифицированную медицинскую помощь имеют возможность жить дольше, в сравнении с населением меньшей доходности. Также на динамику индекса продолжительности жизни, в том числе показателя смертности младенцев и смертности матерей влияют состояние медицины и здравоохранения, уровень социального обеспечения населения страны. [12, с. 128] Что же касается показателя материнской смертности, то здесь можно наблюдать нестабильную картину развития.

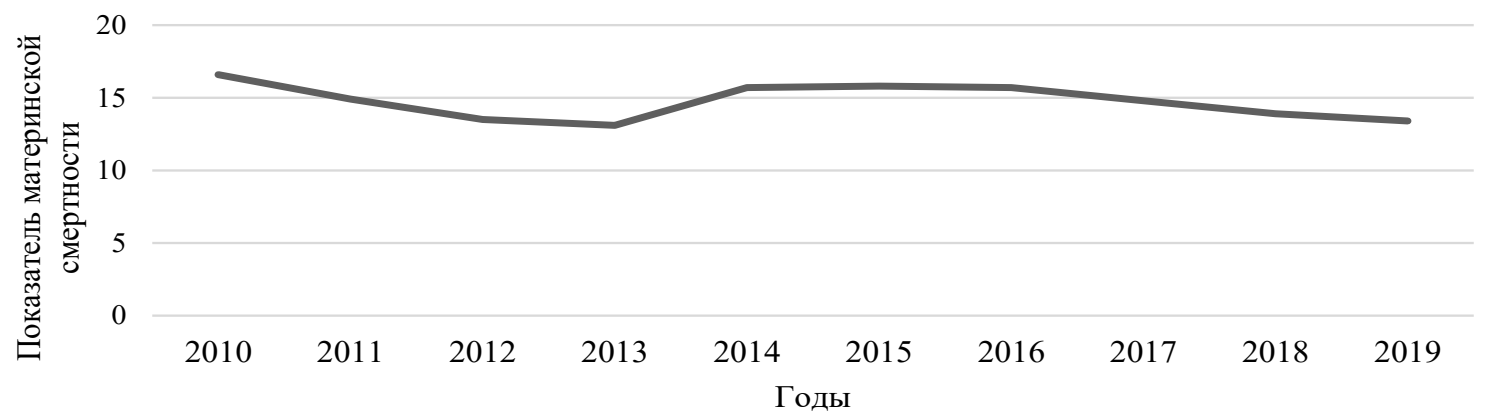

Рисунок 3 - Коэффициент материнской смертности, на 100000 родившихся

Figure 3 - Maternal mortality rate, per 100,000 births

Примечание - Составлено авторами по источнику [14]

Из рисунка 3 видно, что с 2010 года по 2013 год этот показатель стремительно понижался. Начиная с 2013 года по 2016 год мы наблюдали увеличение этого показателя, а с 2016 года снова его понижение. Понижения этого показателя происходит в силу улучшения показателя здоровья людей вследствие увеличения объёмов финансовых вливаний в сферу здравоохранения. В Казахстане активно строятся объекты здравоохранения, улучшается процесс оснащения специальным оборудованием медицинские учреждения. [15, c. 197]

Анализ факторов второго блока позволяет сделать вывод, что ситуация в стране за анализируемый период менялась циклично. На рисунке 4 можно увидеть ситуацию по обеспечению ученическими местами в образовательных школах, что влияет на степень удовлетворения уровнем образовательной системы в стране.

Низким обеспечением ученическими местами в школах, что вероятно связано, в первую очередь, с демографической ситуа-цией характеризуются 2010, 2016 и 2019 годы. В общей структуре расходов в образование, расходы населения на получение образовательных услуг в большей степени приходится на получение высшего и дошкольного образования. Чуть менее $1 \%$ составляют расходы на получение начального образования и общего среднего образования. В Казахстане делаются попытки координации системы переподготовки и подготовки населения, а также попытки по достижению баланса между выпускниками всех уровней образовательных школ и рынками труда.

В Казахстане с 2013 года определяется тенденция увеличения количества экономически активных людей в возрастной категории от 15 лет на 207000 человек с одновременным ростом количества безработных почти на 2000 человек. Такая ситуация отражает усиление качества образовательных услуг в Казахстане и покрытием, в связи с этим, потребностей рынка труда, поскольку основным фактором конкурентоспособности человека на рынке труда является именно уровень его образованности и степень квалифицированности. В стране около $62 \%$ экономически активного населения имеют высшее образование (около 30\%) и средне профессиональное образование (около $32 \%$ ). 
Показателем уровня образования определяется обеспечение работой, то есть увеличение уровня образованности влечёт за собой повышение уровня занятости и понижение уровня безработицы. Соответственно, намного высоким становится показатель уровня безработицы и понижается уровень занятос- ти среди экономически активного населения, которые не имеют профессиональное образование. Система предоставления образовательных услуг в общем контексте всех социальных и экономических показателей в необходимой мере обеспечивает получение населен

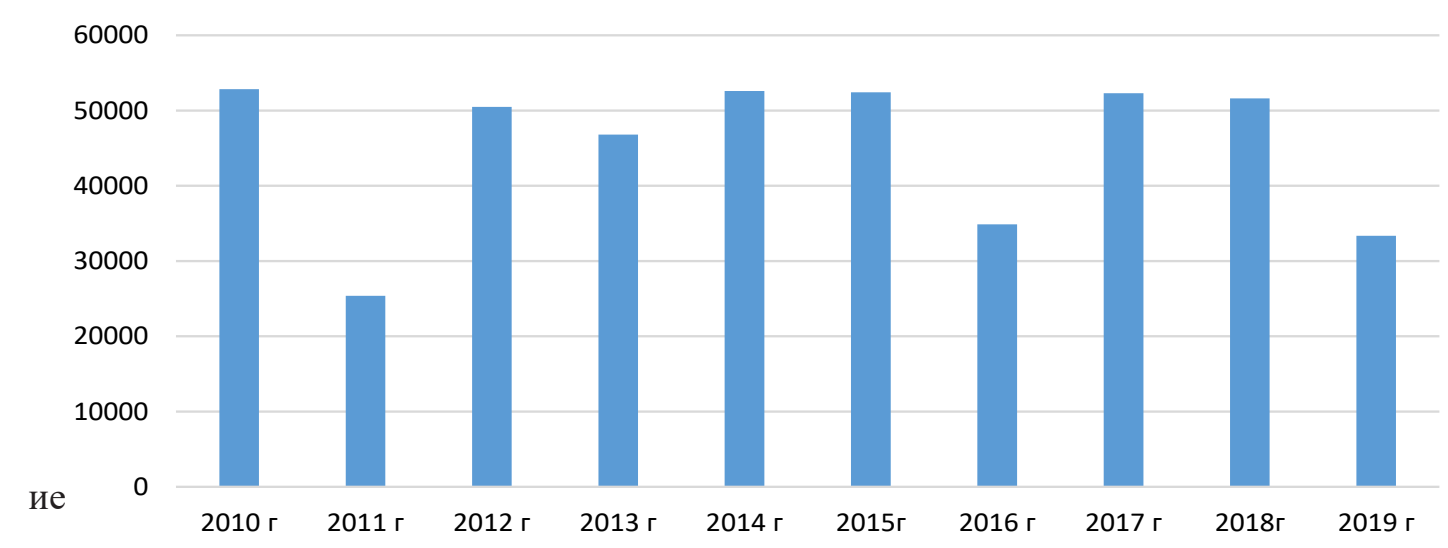

Рисунок 4 - Ученические места в образовательных школах, введённых в эксплуатацию

Figure 4 - Student places in educational schools put into operation

Примечание - Составлено авторами по источнику [14].

Анализ валового внутреннего продукта на душу населения также позволяет сделать выводы по человеческому развитию. На рисунке 5 покажем состояние валового внутреннего продукта на душу населения в
Казахстане за период с 2010 по 2019 годы (расчёт производится в американских долларах в соответствии с паритетом покупательной способности национальных денежных единиц).

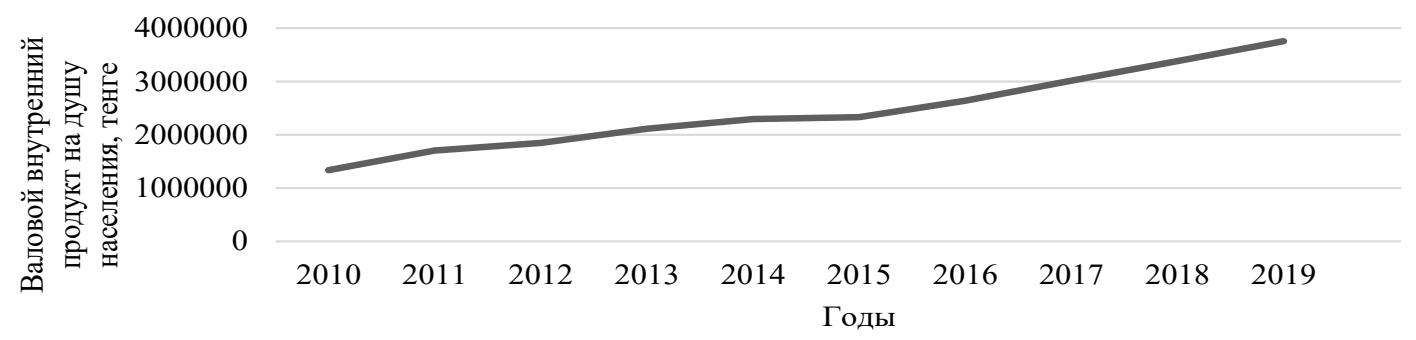

Рисунок 5 - Валовой внутренний продукт на душу населения в Казахстане за 2010 - 2019 гг, тенге Figure 5 - Gross domestic product per capita in Kazakhstan for 2010 - 2019, tenge

Примечание - Составлено авторами по источнику [14]

За анализируемый период с 2010 по 2019 годы мы видим устойчивую тенденцию к росту этого показателя. (расчёт производится в американских долларах в соответствии c паритетом покупательной способности национальных денежных единиц). Но то обстоятельство, что экономический рост не может всецело отражать уровень человеческого развития, обесценивает значимость этого показателя в общей структуре индекса человеческого развития. [16, часть 1]

Таким образом, показатель реального валового продукта на душу населения не показывает никаких диспропорций в механизме распределения доходов, в том числе существующих ограничений в возможностях людей. В то время как именно наличие диспропорций или их отсутствие служит 


\section{DEMOGRAPHY, HUMAN RESOURCES AND THE LABOR MARKET}

индикатором человеческого развития, так, например, равная степень распределения доходов является дополнительным фактором человеческого развития. В связи с чем показатель реальных денежных доходов, который учитывает такие диспропорции, представляет собой важную дополнительную характеристику человеческого развития.

Из рисунка 6 видно, что за последние два года темпы роста доходов населения Казахстана сократились в реальном выражении. Несмотря на постоянную положительную динамику номинальных доходов, темпы роста реальных доходов населения продолжают снижаться. На фоне высокого инфляционного давления в 2015 году и вновь в 2020 году, наблюдается падение темпов роста реальных доходов, что оказывает негативное влияние на человеческое развитие в стране. Усугубляет ситуацию синхронность динамики реальных доходов населения с темпами роста ВВП. Более детальный анализ ИЧР через ранжирование населения на группы по возрастанию среднедушевых располагаемых ресурсов, а затем квинтильного деления на пять равных 20\%-х доходных групп позволяет выявить более реалистичную картину относительно уровня человеческого развития.

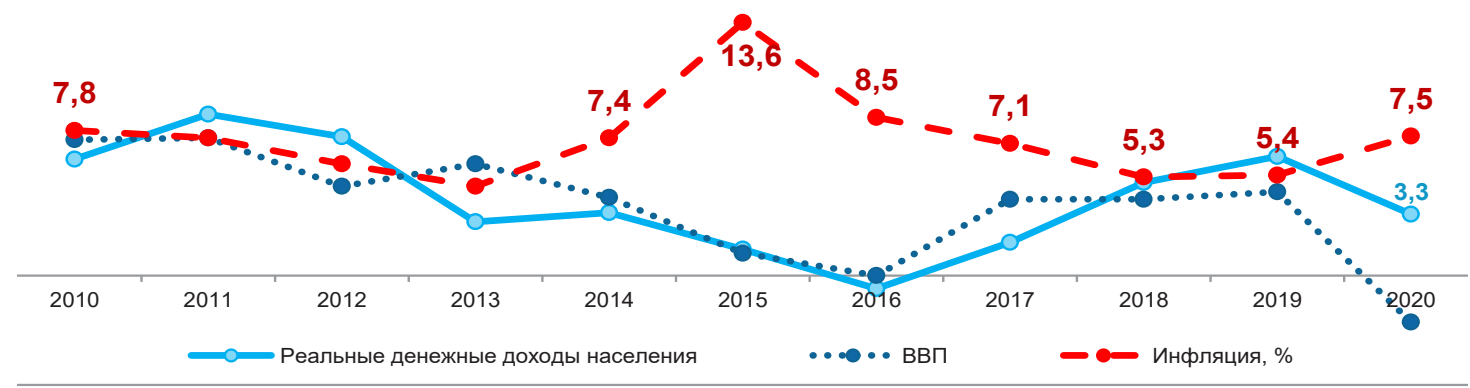

Рисунок 6 - Динамика реальных денежных доходов населения, ВВП и инфляции, \% к предыдущему году

Figure 6 - Dynamics of real money incomes of the population, GDP and inflation, \% to the previous year

Примечание - Составлено авторами

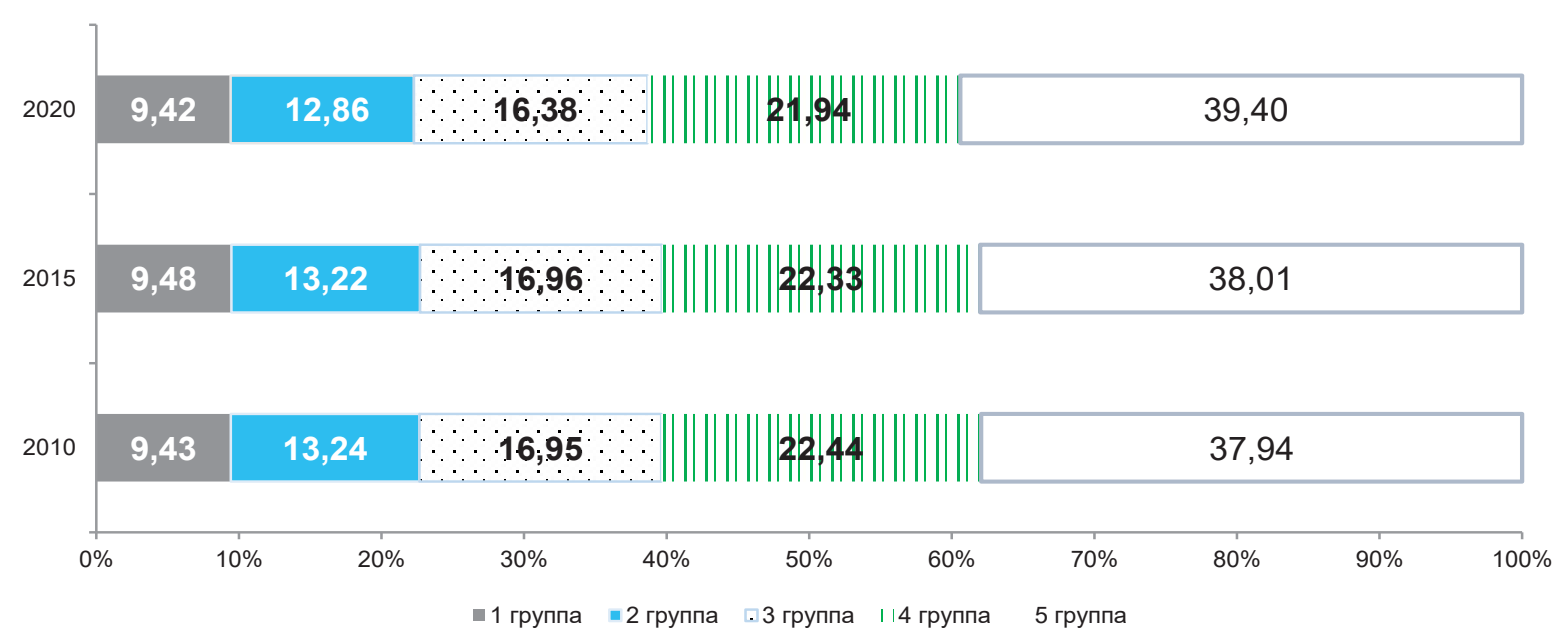

Рисунок 7 - Дифференцированность доходов квинтильных групп населения, \%

Figure 7 - Differentiation of income of quintile groups of the population, \%

Примечание - Составлено авторами 
Из рисунка 7 можно увидеть, снижение реальных доходов домашних хозяйств затронуло группы населения с наименьшим уровнем дохода и почти не коснулось высокодоходных групп. Существующую диспропорцию в распределении доходов между квинтильными группами населения показывает анализ коэффициента Джини, который составил в 2010 г. - 0,278 (в 2020 г. - 0,291). То есть на 20\% наименее обеспеченного населения приходится всего 9,42\% совокупного дохода, в то же время как на 20\% наиболее обеспеченного населения приходится 39,4\% совокупного дохода населения в то же время. Одной из основных причин усиления существующего неравенства в распределении доходов является несовершенство существующей системы перераспределения доходов в экономике. [17, глава 3]

В перспективе в Казахстане необходимым является проведение государственной политики с целью влияния на продолжительность и уровень жизни и на другие компоненты индекса человеческого развития, устойчивое развитие и повышение рейтинга среди государств с высоким уровнем индекса человеческого развития.

\section{Заключение}

Таким образом, в завершении статьи можно сделать следующие выводы:

1. В статье сделан акцент на анализе показателей первого и второго блоков оценки ИЧР, поскольку в агрегированном виде индекс может скрыть факт того, что группы народонаселения страны имеют дифференцированные уровни своего развития (обусловленные регионом, типом местности), поэтому получить более детальную и полную информацию, на наш взгляд, можно только через его разукрупнение.

2. Выделена структура блоков оценки ИЧР: в первый блок включены здоровье населения, демография (уровень рождаемости, уровень смертности), продолжительность жизни. Во втором блоке - показатели удовлетворённости людей условиями жизни (достатком, жильём, питанием, работой), удовлетворённости социальным положением в государстве (организацией власти, способностью решения острых проблем социального характера), доступностью медицинских и образовательных услуг, экологической ситуацией в стране. В третьем блоке - показатели духовного развития.

3. Сделан анализ реального валового продукта на душу населения в Казахстане, в результате сделан вывод о том, что он не показывает диспропорций в механизме распределения доходов (в то время как именно наличие диспропорций или их отсутствие служит индикатором человеческого развития, так, например, равная степень распределения доходов является дополнительным фактором человеческого развития). В связи с чем сделан вывод, что именно показатель реальных денежных доходов, который учитывает такие диспропорции, представляет собой важную дополнительную характеристику человеческого развития

4. В результате анализа квинтильного деления населения на группы определена одна из основных причин усиления существующего неравенства в распределении доходов - это несовершенство существующей системы перераспределения доходов в экономике.

При всей позитивной динамике Казахстану есть куда двигаться и стремиться, развивать духовный потенциал, нравственную силу нации, что представляет собой основополагающую составляющую, предопределяющую всё развитие системного человеческого развития.

\section{Список использованных источников}

1. Currie, J., Schwandt, H. (2016). Mortality inequality: The good news from a county-level approach. The Journal of Economic Perspectives, 30(2), 29-52. https://doi.org/10.1257/jep.30.2.29

2. Kaneva, M.A., Avksent'ev, N.A., \& Bajdin, V.M. (2015). Gotovnost' platit' za dobrovol'noe medicinskoe strahovanie na uslovijah sofinansirovanija: regressionnyj analiz. Finansovyj zhurnal, 5(27), 80-90

3. Laupacis, A., et al. (1992). How attractive does a new technology have to be to warrant adoption and utilization? Tentative guidelines for using clinical and economic evaluations. Canadian Medical Association Journal, 146, 473-481

4. Danyliv, A., et al. (2013). Willingness to pay for physician services at a primary contact in Ukraine: results of a contingent valuation study. BMC Health Services Research, 13, 208. https://doi. org/10.1186/1472-6963-13-208

5. Grundmann, R \& Stehr, N. (2001). Why is Werner Sombart Not a Part of the Core of Classical Sociology?, 1 (2), 257-287. https://doi.org/ $10.1177 /$ 14687950122232558

6. Becker, G.S. (1993). Human Capital: A Theoretical and Empirical Analysis with Special Reference to Education. - Third Edition. - Chicago and London: The University of Chicago Press. 4(20), 110-130. ISBN 0-226-04119-0.

7. Громов И. А., Мацкевич А. Ю., Семёнов В.А. (1996). Формальная социология Г. Зиммеля, $1(8), 1-28$

8. Faden, R. \& Leplege, A. (1992). Assessing 
quality of life: Moral implications for clinical practice. Medical Care, 5(1), 166-175

9. Спанкулова Л.С., Нурулы Е., Керимбаев A.P., Аймаханова А.Ш. (2021). Влияние социально-экономических факторов на готовность населения поддерживать и накапливать капитал здоровья. Экономика: стратегия и практика, 16(3), 177-191. https://doi.org/10.51176/1997-9967-2021-3177-191

10. Tambor, M., et al. (2014). Willingness to pay for publicly financed health care services in Central and Eastern Europe: Evidence from six countries based on a contingent valuation method. Social Science \& Medicine, 116, 193-201

11. Фахрутдинова Е. В. (2010). Качество жизни населения в системе социально-экономических отношений: институциональный подход. Диссертация на соискание учёной степени доктора экономических наук. Казанский государственный финансово-экономический институт. Казань.

12. Хаджалова Х.М. (2013). Институциональные основы регулирования качества жизни в регионах. Региональные проблемы преобразования экономики, 4(1), 290-299.

13. Тютюнникова С.В., Бервено О.В. (2014) Институциональное обеспечение качества жизни. Институты и механизмы регулирования в условиях глобальной нестабильности. Монография по материалам XII Международной научно-практической интернет-конференции. Ростов-наДону, 63-172.

14.Сайт Бюро национальной статистики Агентства по стратегическому планированию и реформам РК. (2020). https://stat.gov.kz/official/ dynamic

15. Spankulova, L.S. (2016). Udovletvorennost' kachestvom zhizni, svjazannogo so zdorov'em $\mathrm{v}$ zavisimosti ot urovnja dohodov naselenija, prozhivajushhih v oblastjah s vysokim jekologicheskim riskom. Psihologicheskoe zdorov'e lichnosti: teorija i praktika: sbornik nauchnyh trudov po materialam III Vserossijskoj nauchno-prakticheskoj konferencii, 128130 .

16. «ПРООН. 2019. Доклад о человеческом развитии за 2019 год. За пределами доходов, за пределами средних значений, за пределами сегодняшнего дня: неравенство в человеческом развитии в 21 веке. Нью-Йорк. (2020). Получено из http://hdr.undp.org/en/content/human-developmentreport -2019

17.Отчёт о человеческом развитии 2020. Следующий рубеж: человеческое развитие и антропоцен. (2020). Получено из URL: http:/hdr. undp.org/en/content/human-development-report-2020

\section{References}

1. Currie, J., Schwandt, H. (2016). Mortality inequality: The good news from a county-level approach. The Journal of Economic Perspectives, 30(2), 29-52. https://doi.org/10.1257/jep.30.2.29

2. Kaneva, M.A., Avksent'ev, N.A., \& Bajdin, V.M. (2015). Gotovnost' platit' za dobrovol'noe medicinskoe strahovanie na uslovijah sofinansirovanija: regressionnyj analiz. Finansovyj zhurnal, 5(27), 80-90

3. Laupacis, A., et al. (1992). How attractive does a new technology have to be to warrant adoption and utilization? Tentative guidelines for using clinical and economic evaluations. Canadian Medical Association Journal, 146, 473-481

4. Danyliv, A., et al. (2013). Willingness to pay for physician services at a primary contact in Ukraine: results of a contingent valuation study. BMC Health Services Research, 13, 208. https://doi. org/10.1186/1472-6963-13-208

5. Grundmann, R. \& Stehr, N. (2001). Why is Werner Sombart Not a Part of the Core of Classical Sociology?, 1 (2), 257-287. https://doi.org/ 10.1177 / 14687950122232558

6. Becker, G.S. (1993). Human Capital: A Theoretical and Empirical Analysis with Special Reference to Education. - Third Edition. - Chicago and London: The University of Chicago Press. - ISBN 0-226-04119-0.

7. Gromov, I. A., Mackevich, A. Ju., Semjonov, V. A. (1996). Formal'naja sociologija G. Zimmelja, 1(8), $1-28$

8. Faden, R. \& Leplege, A. (1992). Assessing quality of life: Moral implications for clinical practice. Medical Care, 5(1), 166-175

9. Spankulova, L.S., Nuruly, E., Kerimbaev, A.R., Ajmahanova, A.Sh. (2021). Vlijanie social'nojekonomicheskih faktorov na gotovnost' naselenija podderzhivat' i nakaplivat' kapital zdorov'ja. Jekonomika: strategija i praktika, 16(3), 177-191. https://doi.org/10.51176/1997-9967-2021-3-177-191

10. Tambor, M., et al. (2014). Willingness to pay for publicly financed health care services in Central and Eastern Europe: Evidence from six countries based on a contingent valuation method. Social Science \& Medicine, 116, 193-201

11. Fahrutdinova, E.V. (2010). Kachestvo zhizni naselenija $\mathrm{V}$ sisteme social'no-jekonomicheskih otnoshenij: institucional'nyj podhod. Dissertacija na soiskanie uchjonoj stepeni doktora jekonomicheskih nauk. Kazanskij gosudarstvennyj finansovojekonomicheskij institut. Kazan'.

12.Hadzhalova, H.M. (2013). Institucional'nye osnovy regulirovanija kachestva zhizni $\mathrm{v}$ regionah. Regional'nye problemy preobrazovanija jekonomiki, 4(1), 290-299.

13.Tjutjunnikova, S.V. \& Berveno, O.V. (2014) Institucional'noe obespechenie kachestva zhizni. Instituty i mehanizmy regulirovanija $\mathrm{v}$ uslovijah global'noj nestabil'nosti. Monografija po materialam XII Mezhdunarodnoj nauchno-prakticheskoj internetkonferencii. Rostov-naDonu, 63-172.

14. Sajt Bjuro nacional'noj statistiki Agentstva po strategicheskomu planirovaniju i reformam RK. (2020). https://stat.gov.kz/official/dynamic

15.Spankulova, L.S. (2016). Udovletvorennost' kachestvom zhizni, svjazannogo so zdorov'em $\mathrm{v}$ zavisimosti ot urovnja dohodov naselenija, prozhivajushhih v oblastjah s vysokim jekologicheskim riskom. Psihologicheskoe zdorov'e lichnosti: teorija i praktika: sbornik nauchnyh trudov po materialam III 
Vserossijskoj nauchno-prakticheskoj konferencii, 128130 .

16. «PROON. 2019. Doklad o chelovecheskom razvitii za 2019 god. Za predelami dohodov, za predelami srednih znachenij, za predelami segodnjashnego dnja: neravenstvo $\mathrm{v}$ chelovecheskom razvitii v 21 veke. N'ju-Jork. (2020). Polucheno iz Http://hdr.undp.org/en/content/human-developmentreport -2019

17. Otchjot o chelovecheskom razvitii 2020 . Sledujushhij rubezh: chelovecheskoe razvitie i antropocen. (2020). Polucheno iz URL: http://hdr.undp. org/en/content/human-development-report-2020

\section{Information about the authors}

* Saule A. Kozhabaeva - Kazakh University of Economics, Finance and International Trade, candidate of Economic Sciences; Kazakhstan, e-mail: s_kozhabayeva@kuef.kz; https://orcid. org / 0000-0002-4586-4465

Baurzhan G. Mukan - Managing Director of JSC Institute for Economic Research, Kazakhstan, e-mail: bmukan_77@ mail.ru

Rakymzhan K. Yelshibayev - JSC Narkhoz University, Kazakhstan, e-mail: rakymzhan.yelshibayev@,bk.ru.

\section{Авторлар туралы мәліметтер}

* Қожабаева С.А. - Қазақ экономика, қаржы және халықаралық сауда университеті, Қазақстан, e-mail: s_ kozhabayeva@kuef.kz; ORCID ID: https: // orcid. org / 0000-0002-4586-4465

Мұқан Б.Ғ. - Экономикалық зерттеулер институты АҚ-ның басқарушы директоры, Қазақстан, е-таil: bmukan_77@mail.ru

Елшібаев Р.К. - АҚ Нархоз университеті,Қазақстан, e-mail: rakymzhan.yelshibayev@, bk.ru.

\section{Информация об авторах}

* Қожабаева С.А. - Казахский университет экономики, финансов и международной торговли, Казахстан, e-mail:s_kozhabayeva@kuef.kz; ORCID ID: https://orcid.org/0000-0002-4586-4465

Мұқан Б.Ғ. - управляющий директор АО Институт экономических исследований, Казахстан, е-таil: bmukan_77@mail.ru

Елшібаев Р.К. - АО Университет Нархоз, Казахстан, e-mail: rakymzhan.yelshibayev@ bk.ru. 